\title{
SUMMER SIGHTINGS OF DWARF MINKE WHALES (BALAENOPTERA ACUTOROSTRATA) OFF THE EASTERN COAST OF RIO DE JANEIRO STATE, BRAZIL
}

\author{
Lucas B. Hassel ${ }^{1}$, Andréa Venturotti ${ }^{1}$, Fagner Augusto de Magalhães ${ }^{1}$, \\ Sandra Cuenca ${ }^{1}$, Salvatore Siciliano ${ }^{1}$ and Fernanda F. C. Marques ${ }^{2}$
}

\begin{abstract}
Twenty-two sightings of dwarf minke whales were made during shore-based surveys for cetaceans conducted from the Pontal do Atalaia headland, Arraial do Cabo, southeastern Brazil, in january 2001. Whales were observed associated with brown boobies, kelp gulls and terns, in apparent feeding behaviour. the white patch on the flippers and shoulder was clearly visible on most whales as the majority of the sightings were made in close proximity to land. the nutrient rich waters of the cabo frio upwelling ecosystem seem to provide a constant food supply for whales and dolphins.

Resumo - Foram reunidas 22 avistagens da baleia-minke-anã a partir de observações de ponto fixo conduzidas em Arraial do Cabo, Sudeste do Brasil, em janeiro de 2001. As baleias encontravam-se associadas com atobás, gaivotões e trinta-réis em aparente comportamento alimentar. As características manchas brancas nas peitorais e ombros foi claramente visível na maioria das baleias uma vez que as avistagens foram realizadas nas proximidades do Pontal do Atalaia. As águas ricas em nutrientes da ressurgência de Cabo Frio parecem fornecer um aporte de alimentos constante para baleias e golfinhos.
\end{abstract}

Keywords: Dwarf Minke Whale; Western South Atlantic; Summer Sightings; Distribution; Behaviour; Associations/Seabirds.

\section{Introduction}

The distribution of the dwarf minke whale (Balaenoptera acutorostrata) in low latitudes extends as far north as $11^{\circ} \mathrm{S}$ in the Pacific Ocean (Arnold et al., 1987). They have been observed off Australia, New Caledonia and New Zealand (e.g. Baker, 1983; Arnold et al., 1987; Arnold, 1997). In Australia, dwarf minkes were recorded from June to December, with peaks in July and August (Arnold et al., 1987). In the Indian Ocean, dwarf minke whales have been reported along the coast of South Africa from April to August, but $92 \%$ of the captures took place in the first half of the whaling season (April to June) (Best, 1985). They are also found up to $7^{\circ} \mathrm{S}$ along the eastern coast of South America (da Rocha and Braga, 1982), and are relatively common in Brazil, Uruguay and Argentina (Baldas and Castello, 1986; Zerbini et al., 1996; 1997). Occurrences in Brazil have been observed throughout the year except in March, with peaks in June to September (Zerbini et al. 1996; 1997). Previous records of dwarf minke whales along the Brazilian coast were based on strandings, incidental, and direct catches, with only a few reliable sightings being available to date.

During a long term monitoring program of the migration of whales along southeastern Brazil, we had the opportunity to record 22 sightings of dwarf minke whales during the 2001 austral summer. We report the behaviour, movements, possible feeding events and associations with seabirds in relation to the presence of dwarf minke whales.

\section{Material and methods}

A long term monitoring program of the migration of humpback (Megaptera novaeangliae) and southern right whales (Eubalaena australis) was initiated in August 1998 using boat and, subsequently, shore-based surveys. The latter were made from the top of the $74 \mathrm{~m}$ high Pontal do
Atalaia, a prominent headland located on the eastern coast of Rio de Janeiro state, Brazil (Fig.1). Daily sightings of whales and dolphins were recorded from 05:30AM to 06:30PM using reticule binoculars (TASCO OffShore 54S) and a spotting scope (Bushnell Spacemaster WA $22 \times 67 \mathrm{~mm})$. Wind direction, weather and sea conditions (Beaufort) were also recorded during all hours of observation. For each sighting the radial angle and reticule reading were recorded, together with the species identification and an estimate of the school size, as well as a description of any observed behaviours. The presence of seabirds associated with each sighting, as well as the seabird species involved, were also noted.

The reticule readings associated with each sighting were later converted to radial distances following Lerczak and Hobbs $(1998 \mathrm{a}, \mathrm{b})$. These radial distances, combined with the radial angles, were then used to calculate the approximate position of each sighting using standard geometry. Although the curvature of the earth was not taken into account when calculating these positions, this effect was likely negligible as radial distances were usually small (ranging from 0.76 to 4.11 nautical miles (nm), with mean $1.61 \mathrm{~nm}$ ). This is supported by the fact that radial distances obtained according to the standard conversion method (Buckland et al., 2001), which does not take the curvature of the earth into account, did not differ by more than $0.01 \mathrm{~nm}$ from radial distances obtained when accounting for the curvature of the earth. No reticule readings were taken from sightings made on January 8 , and from two sightings made on January 15; therefore their geographic positions were not computed.

\section{Results}

Twenty-two sightings of dwarf minke whales were made from the headland of Pontal do Atalaia from 8-17 January 2001 (Table 1). It is possible that the sightings might have

\footnotetext{
'Grupo de Estudos de Mamíferos Marinhos da Região dos Lagos (GEMM-Lagos), Laboratório de Ecologia, Departamento de Endemias Samuel Pessoa, Escola Nacional de Saúde Pública/FIOCRUZ. Rua Leopoldo Bulhões, 1480 - térreo, Manguinhos, Rio de Janeiro, RJ, 21041-210, Brazil. ${ }^{2}$ Rua Prof. Sabóia Ribeiro 83/1003, Rio de Janeiro, RJ, 22430-130, Brazil.
} 


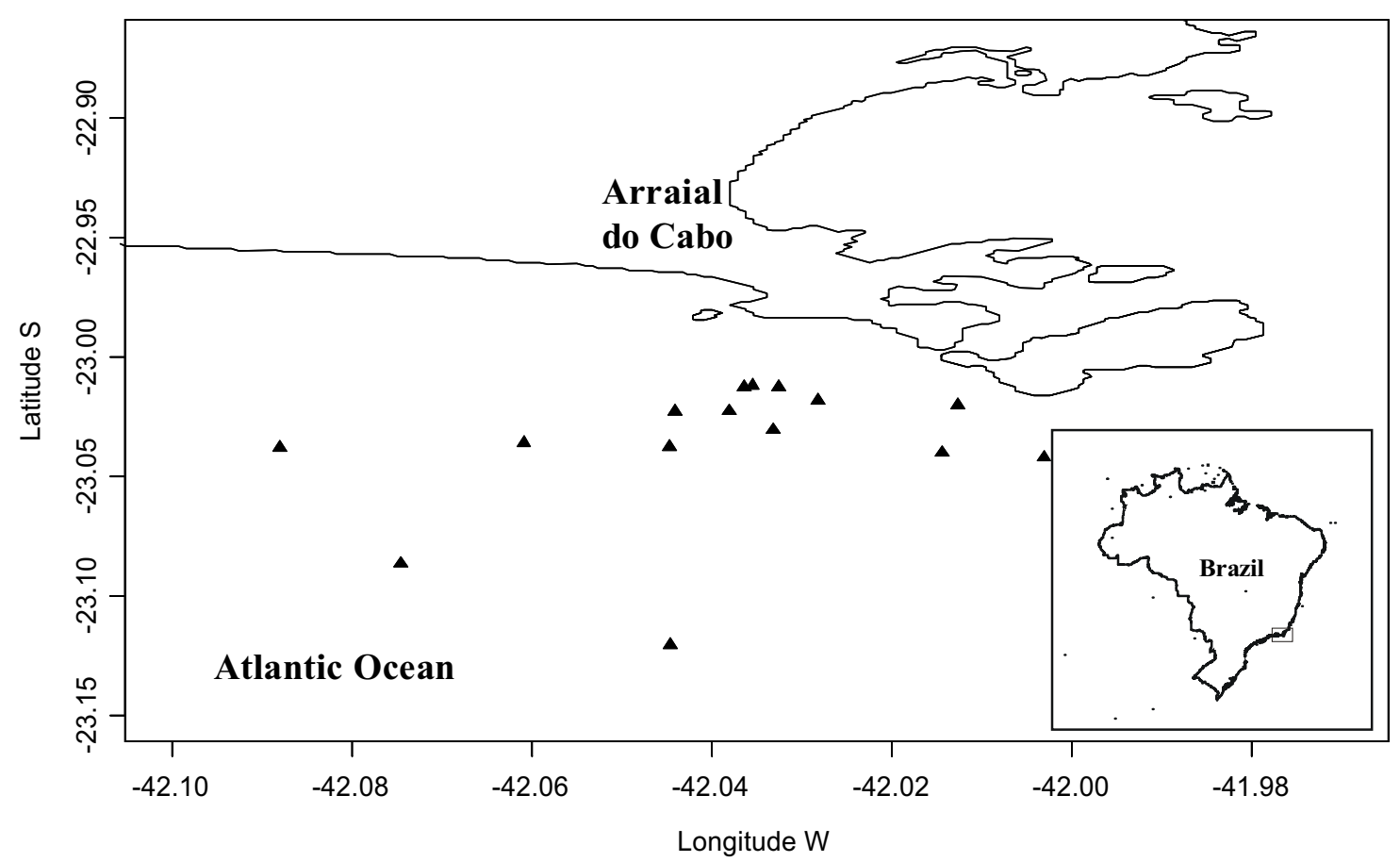

Figure 1. Dwarf minke whale sighting locations off Arraial do Cabo, eastern Rio de Janeiro state, Brazil.

Table 1. Summer sightings of dwarf minke whales off Arraial do Cabo, Brazil, 8-17 January 2001.

\begin{tabular}{|c|c|c|c|c|c|c|c|c|}
\hline Date & $\begin{array}{l}\text { Observation } \\
\text { start }\end{array}$ & $\begin{array}{l}\text { Observation } \\
\text { end }\end{array}$ & $\begin{array}{l}\text { Group } \\
\text { size }\end{array}$ & $\begin{array}{l}\text { Associations } \\
\text { with seabirds }\end{array}$ & $\begin{array}{c}\text { Radial } \\
\text { distance }(\mathrm{nm})\end{array}$ & Angle & Latitude & Longitude \\
\hline Jan. 8 & 14:06 & 15:01 & 1 & brown boobies & -- & 303 & -- & -- \\
\hline Jan. 8 & $15: 21$ & $15: 58$ & 1 & brown boobies & -- & 319 & -- & -- \\
\hline Jan. 8 & $16: 37$ & $17: 04$ & 2 & brown boobies & -- & 308 & -- & -- \\
\hline Jan. 8 & $17: 19$ & $17: 45$ & 1 & $\begin{array}{l}\text { brown boobies } \\
\text { and terns }\end{array}$ & -- & 311 & -- & -- \\
\hline Jan. 8 & 18:07 & $18: 28$ & 2 & brown boobies & -- & 309 & -- & -- \\
\hline Jan. 10 & 11:46 & 11:55 & 1 & & 1.12 & 221 & $23^{\circ} 01^{\prime} 21^{\prime \prime} \mathrm{S}$ & $042^{\circ} 02^{\prime} 17^{\prime \prime} \mathrm{W}$ \\
\hline Jan. 10 & $14: 20$ & 15:00 & 2 & brown boobies & 3.43 & 212 & $23^{\circ} 05^{\prime} 11^{\prime \prime} \mathrm{S}$ & $042^{\circ} 04^{\prime} 28^{\prime} \mathrm{W}$ \\
\hline Jan. 10 & $16: 18$ & $16: 26$ & 1 & & 1.90 & 228 & $23^{\circ} 02^{\prime} 09^{\prime \prime} \mathrm{S}$ & $042^{\circ} 03^{\prime} 39^{\prime} \mathrm{W}$ \\
\hline Jan. 10 & $16: 52$ & $17: 35$ & 1 & $\begin{array}{l}\text { brown boobies } \\
\text { and kelp gull }\end{array}$ & 0.76 & 228 & $22^{\circ} 00^{\prime} 45^{\prime \prime} \mathrm{S}$ & $042^{\circ} 01^{\prime} 57^{\prime} \mathrm{W}$ \\
\hline Jan. 10 & $18: 22$ & 18:45 & 2 & & 2.59 & 239 & $23^{\circ} 02^{\prime} 16^{\prime \prime} \mathrm{S}$ & $042^{\circ} 05^{\prime} 17^{\prime} \mathrm{W}$ \\
\hline Jan. 11 & 05:44 & 07:15 & 1 & & 1.24 & 208 & $23^{\circ} 01^{\prime} 50^{\prime \prime S}$ & $042^{\circ} 01^{\prime} 59^{\prime} \mathrm{W}$ \\
\hline Jan. 12 & 07:07 & 08:19 & 1 & & 4.11 & 193 & $23^{\circ} 07^{\prime} 13^{\prime \prime} \mathrm{S}$ & $042^{\circ} 02^{\prime} 41^{\prime \prime} \mathrm{W}$ \\
\hline Jan. 12 & $14: 50$ & $15: 20$ & 1 & brown boobies & 1.24 & 227 & $23^{\circ} 01^{\prime} 22^{\prime \prime} \mathrm{S}$ & $042^{\circ} 02^{\prime} 39^{\prime} \mathrm{W}$ \\
\hline Jan. 12 & $15: 55$ & $17: 00$ & 1 & & 1.61 & 215 & $23^{\circ} 02^{\prime} 15^{\prime \prime S}$ & $042^{\circ} 02^{\prime} 41^{\prime \prime} \mathrm{W}$ \\
\hline Jan.13 & 06:09 & $06: 26$ & 1 & brown boobies & 1.50 & 168 & $23^{\circ} 02^{\prime} 31^{\prime \prime \prime} \mathrm{S}$ & $042^{\circ} 00^{\prime} 11^{\prime \prime} \mathrm{W}$ \\
\hline Jan. 13 & 06:45 & $07: 12$ & 1 & & 1.41 & 181 & $23^{\circ} 02^{\prime} 24^{\prime \prime} \mathrm{S}$ & $042^{\circ} 00^{\prime} 52^{\prime \prime} \mathrm{W}$ \\
\hline Jan. 14 & $12: 30$ & $12: 57$ & 1 & & 0.85 & 233 & $23^{\circ} 00^{\prime} 45^{\prime \prime} \mathrm{S}$ & $042^{\circ} 02^{\prime} 11^{\prime \prime} \mathrm{W}$ \\
\hline Jan. 14 & 13:43 & $14: 10$ & 1 & & 0.82 & 212 & $23^{\circ} 01^{\prime} 05^{\prime \prime} \mathrm{S}$ & $042^{\circ} 01^{\prime} 41^{\prime \prime} \mathrm{W}$ \\
\hline Jan. 15 & 08:56 & 10:00 & 1 & brown boobies & -- & 298 & -- & -- \\
\hline Jan. 15 & $10: 25$ & $11: 40$ & 1 & brown boobies & -- & 305 & -- & -- \\
\hline Jan. 15 & $14: 40$ & $14: 50$ & 1 & & 0.82 & 233 & $23^{\circ} 01^{\prime} 12^{\prime \prime} \mathrm{S}$ & $042^{\circ} 00^{\prime} 46^{\prime \prime} \mathrm{W}$ \\
\hline Jan. 17 & $15: 34$ & $15: 50$ & 1 & brown boobies & 0.76 & 178 & $23^{\circ} 01^{\prime} 12^{\prime \prime} \mathrm{S}$ & $042^{\circ} 00^{\prime} 46^{\prime \prime} \mathrm{W}$ \\
\hline
\end{tabular}


corresponded to the same group of (1-2) individuals. Most sightings were made in excellent to good weather conditions, with sea state varying between Beaufort 1-3 and prevailing northeasterly winds. Group size varied between one to two whales; no calves were observed. All sightings were located well into the continental shelf, in waters less than $200 \mathrm{~m}$ deep. Sea surface temperature ranged from $13^{\circ} \mathrm{C}$ to $27^{\circ} \mathrm{C}$ (Instituto de Estudos do Mar Almirante Paulo Moreira/IEAPM, Praia dos Anjos, Arraial do Cabo, RJ 28930-000, Brazil, unpublished data). The identification of dwarf minke whales was based on their small body size relative to that of other whales commonly seen in the region (e.g. Bryde's whales), and external coloration (the conspicuous white shoulder patch and white coloration at the base of the flipper; Best, 1985; Arnold et al., 1987). It was noticed, at least in some occasions, that the whales presented a white shoulder patch and white pigmentation on the flippers. In addition, dwarf minke whales occur closer inshore than ordinary minke whales in waters off South Africa and off Brazil (e.g. Best, 1985; Zerbini et al., 1997; 2000).

Dwarf minke whales were observed in possible foraging behaviour on at least 12 (54\%) of the sightings. On such occasions whales were associated with brown boobies (Sula leucogaster), and less frequently with kelp gulls (Larus dominicanus) and terns (possibly Sterna eurygnatha, $S$. hirundinacea, S. hirundo or S. maxima). The attributed feeding behaviour was connected to the presence of large numbers of these seabirds actively catching prey, possibly Brazilian sardines (Sardinella brasiliensis) and/or euphausiids. On other 14 occasions dwarf minke whales were observed moving erratically in different directions. This behaviour is possibly associated with search for prey aggregations or avoidance of boats. The presence of whales, dolphins and/ or seabirds usually attracts fishing boats as well as tour (whale-watching) boats. In general dwarf minke whales avoided the presence of boats, moving to other areas nearby.

\section{Discussion}

In contrast with ordinary minke whales, which migrate to high latitude feeding grounds during the summer, it has been suggested that dwarf minke whales may spend the summer in mid-latitudes, in which case they must feed in sub-tropical and warm temperate waters (Zerbini et al., 1997). The behaviour observed during some of the sightings made off Arraial do Cabo suggests that some of the animals were feeding, possibly on fish or euphausiids. Secchi et al. (1993) reported the presence of Euphausia similis in the stomach contents of dwarf minke whales incidentally caught off Rio Grande, southern Brazil. In the southeastern continental shelf, from Cabo de Santa Marta Grande $\left(\sim 28^{\circ} \mathrm{S}\right)$ to Cabo Frio $\left(\sim 23^{\circ} \mathrm{S}\right)$, total biomass of euphausiids may represent $3 \%$ to $12 \%$ of the zooplanktonic fauna. E. similis, the most abundant euphausiid species, and Tysanoessa gregaria, are reported to occur in neritic waters (Tôha, 1981; Muxagata, 1999). This raises the possibility that some dwarf minke whales may feed on euphausiids along the Brazilian coast. Fish constitute a major part of the food of minke whales in the northern hemisphere (e.g. Mitchell, 1975; Jonsgård, 1982; Sigurjónsson et al., 2000). The region of Arraial do Cabo is strongly influenced in the summer by the socalled Cabo Frio upwelling ecosystem, a nutrient rich water mass generated by the continuous penetration of deep South Atlantic Central Water (Valentin, 2000). Fish and squid are abundant in the region throughout the year, supporting a substantial local fishery (Costa et al., 1990; Fagundes-Netto and Gaelzer, 1991; Haimovici and Perez, 1991; Costa and Fernandes, 1993; Valentin, 2000). At least 29 species of cetaceans are known to occur in these waters, including some that are clearly associated with these enriched waters, such as long-beaked common dolphins (Delphinus capensis) and Atlantic spotted dolphins (Stenella frontalis) (Siciliano et al., 2001). It is possible that dwarf minke whales are also taking advantage of the productive upwelling waters off Arraial do Cabo.

Despite continuous survey effort at Arraial do Cabo throughout and beyond the austral summer months over the years 1999-2001, dwarf minke whales have only been sighted over a 10-day period in January 2001. Additional sightings at nearby Bacia de Campos have also been reported during April 1995 (reported in Zerbini et al., 1997), indicating the possibility that some dwarf minke whales present a wide spatial and temporal use of coastal habitats off Brazil. However, dedicated surveys, covering wider spatial and temporal scales, are required to confirm this hypothesis.

\section{Acknowledgements}

Funding for field work was provided by Redley Surfing and Board Riding Co., and CAPES. We thank Greg Donovan for his encouragement and comments on an earlier draft of this manuscript. Two anonymous referees provided constructive comments to this article.

\section{References}

Arnold, P.W. (1997) Occurrence of dwarf minke whales (Balaenoptera acutorostrata) on the Northern Great Barrier Reef, Australia. Reports of the International Whaling Commission 47: 419-424.

Arnold, P., Marsh, H. and Heinsohn, G. (1987) The occurrence of two forms of minke whales in the east Australian waters with a description of external characters and skeleton of the diminutive or dwarf form. Scientific Reports of the Whales Research Institute 38: 1-46.

Baldas, M.I. and Castello, H.P. (1986) Sobre el hallazgo de ejemplares juveniles de ballena minke (Balaenoptera acutorostrata) en el estuario del Rio de la Plata y sur del Brasil. Pages 1-13 in Castello, H.P. (Ed.) Actas I Reunión de Trabajo de Expertos en Mamíferos Acuáticos de América del Sur, 25-29 Junio 1984, Buenos Aires, Argentina.

Best, P.B. (1985) External characters of southern minke whales and the existence of a diminutive form. Scientific Reports of the Whales Research Institute 36: 1-33.

Buckland, S.T., Anderson, D.R., Burnham, K.P., Laake, J.L., Borchers, D.L. and Thomas, L. (2001) Introduction to distance sampling: estimating abundance of biological populations. Oxford University Press, London. 
Costa, P.A.S., Moreira, P. and Haimovici, M. (1990) A pesca de polvos e lulas no litoral do Rio de Janeiro. Ciência e Cultura 42: 1124-1130.

Costa, P.A.S. and Fernandes, F. da C. (1993) Seasonal and spatial changes of cephalopods caught in the Cabo Frio (Brazil) upwelling ecosystem. Bulletin of Marine Science 52:751-759.

Fagundes-Netto, E. and Gaelzer, L.R. (1991) Associações de peixes bentônicos e demersais na região de Cabo Frio, RJ, Brasil. Nerítica 6: 139-156.

Haimovici, M. and Perez, J.A.A. (1991) Coastal cephalopod fauna of southern Brazil. Bulletin of Marine Science 49:221-230.

Jonsgård, ̊.. (1982) The food of minke whales (Balaenoptera acutorostrata) in northern North Atlantic waters. Reports of the International Whaling Commission 32: 259-262.

Lerczak, J.A. and Hobbs, R. C. (1998a) Calculating sighting distances from angular readings during shipboard, aerial and shore-based marine mammal surveys. Marine Mammal Science 14: 590-599.

Lerczak, J.A. and Hobbs, R.C. (1998b) Errata: Calculating sighting distances from angular readings during shipboard, aerial and shore-based marine mammal surveys. Marine Mammal Science 14: 903.

Mitchell, E.D. (1975) Trophic relationships and competition for food in northwest Atlantic whales. Proceedings of the Canadian Society of Zoology. Annual Meeting, Fredericton, New Brunswick, June 2-5, 1974, pp.123-129.

Muxagata, E. (1999) Avaliação da biomassa e distribuição zooplanctônica na plataforma continental sudeste brasileira durante o inverno de 1995. MSc Thesis. Fundação Universidade Federal do Rio Grande, Rio Grande. 177pp.

Valentin, J.L. (2000) The Cabo Frio Upwelling System, Brazil. Pages 97-104 in Seeliger, U. and Kjerfve, B. (Eds.) Coastal marine ecosystems of Latin America. Ecological Studies, Vol. 144. Springer-Verlag, Berlin.
Secchi, E.R., L. Dalla Rosa, A. N. Zerbini, A. B. Greig, L. M. Möller and L. Barcellos (1993) Progress on the knowledge of cetaceans in southern Brazil. Page 97 in Abstracts X Biennial Conference on the Biology of Marine Mammals, Galveston, Texas, USA.

Siciliano, S., Demari e Silva, E., Fernandes, T. and Hassel, L.B. (2001) Cetaceans of the Cabo Frio upwelling ecosystem, southeastern Brazil: a review and comparisons with two other western South Atlantic areas. Page 12 in Abstracts, XV Annual Conference of the European Cetacean Society, Rome, Italy.

Sigurjónsson, J., Galan, A. and Víkingsson, G.A. (2000) A note on stomach contents of minke whales (Balaenoptera acutorostrata) in Icelandic waters. NAMMCO Scientific Publications 2: 82-90.

Tôha, F.A.L. (1981) Sistemática e distribuição geográfica de Euphausiacea (Crustacea) ao largo das costas sul do Brasil (Lat. $22^{\circ} \mathrm{S}-30^{\circ} \mathrm{S}$ ). MSc Thesis. Universidade de São Paulo, São Paulo. 109pp.

Zerbini, A.N., Secchi, E.R., Siciliano, S. and Simões-Lopes, P.C. (1996) The dwarf form of the minke whale, Balaenoptera acutorostrata Lacépède, 1804, in Brazil. Reports of the International Whaling Commission 46: 333-340.

Zerbini, A.N., Secchi, E.R., Siciliano, S. and Simões-Lopes, P.C. (1997) Review of the occurrence and distribution of whales of the genus Balaenoptera along the Brazilian coast. Reports of the International Whaling Commission 47: 407-417.

Zerbini, A.N., da Rocha, J.N., Andriolo, A., Siciliano, S., Moreno, I.B., Lucena, A., Simões-Lopes, P.C., Pizzorno, J.L. Danilewicz, D. and Bassoi, M. (2000) An outline of the cetacean sighting surveys conducted off the northeastern Brazilian coast with preliminary abundance estimation of minke whales. Paper SC/52/IA18 presented to the IWC Scientific Committee, July 2000 (unpublished). 14pp. 